ARTIKEL PENELITIAN

\title{
HUBUNGAN TINGKAT PENGETAHUAN TERHADAP MOTIVASI IBU \\ HAMIL TRIMESTER TIGA DALAM MELAKSANAKAN INISIASI MENYUSUI DINI DI PUSKESMAS MEDAN DENAI
}

\author{
Amalia Farah Mutia Nur Hasibuan', Ika Nopa² \\ ${ }^{1}$ Fakultas Kedokteran, Universitas Muhammadiyah Sumatera Utara \\ ${ }^{2}$ Bagian Ilmu Kesehatan Masyarakat, Fakultas Kedokteran, Universitas Muhammadiyah \\ Sumatera Utara
}

Email : $\underline{\text { amaliafarah150@yahoo.co.id }}$

\begin{abstract}
Early Breastfeeding Initiation (IMD / Inisiasi Menyusui Dini) is the first time a mother gives breast milk to her baby in the first 1 hour of birth. The implementation of Early Breastfeeding Initiation has several benefits, one of which is to reduce infant mortality. However, the prevalence of the implementation of Early Breastfeeding Initiatives in Indonesia is still very low. The purpose of the study was to determine whether there was a relationship between the level of knowledge of the motivation of third trimester pregnant women in initiating early breastfeeding initiation at Puskesmas Medan Denai. The type of this study was the descriptive analytic study with the cross-sectional design. The subjects in this study were third trimester pregnant women in the Puskesmas Medan Denai in August 2018, totaling 50 people. This research technique uses purposive sampling and data analysis using the chi-square test. Retrieving data through filling in questionnaires. The results of the study showed that there were 24 third trimester pregnant women who had sufficient level of knowledge (48\%) and third-trimester pregnant women who had strong motivation as many as 29 people (58\%), the chi-square test results obtained p-value $=0.026$. Conclusion,There is a relationship between the level of knowledge on the motivation of third-trimester pregnant women in initiating early breastfeeding at Puskesmas Medan Denai
\end{abstract}

Keywords: Early Breastfeeding Initiation, Knowledge Level, Motivation 
Vol 1 No 1 Desember 2019

\section{PENDAHULUAN}

Inisiasi Menyusui Dini (IMD) merupakan saat pertama ibu memberikan ASI kepada bayinya dalam 1 jam pertama kelahiran. ${ }^{1}$ Proses ini memberikan kesempatan kepada bayi untuk menyusu sendiri dengan melakukan kontak kulit kepada ibunya. $^{2}$

\section{Pelaksanaan}

Inisiasi

Menyusui Dini (IMD) ini sangat bermanfaat karena bayi akan mendapatkan ASI pertama ibu yang kaya akan nutrisi dan zat kekebalan tubuh yang disebut Kolostrum. ${ }^{3}$

Manfaat lain yang dapat dirasakan ialah menghasilkan perlindungan antibodi untuk bayi baru lahir, mencegah morbiditas seperti diare, pneumonia, sepsis neonatus, mengurangi obesitas maupun diabetes di kemudian hari, mengurangi perdarahan postpartum pada ibu, serta menurunkan angka kematian bayi baru lahir. ${ }^{4}$

Menurut World Health Organization (WHO) 2015, angka kematian neonatal adalah 19 per 1000 kelahiran hidup. ${ }^{5}$

Sustainable Development Goals (SDGs) salah satu program para pemimpin dunia yang memiliki tujuan pada tahun 2030 semua negara dapat menurunkan angka mortalitas neonatus sebesar 12 kematian per 1.000 kelahiran. ${ }^{6}$ Di Indonesia pada tahun 2015, berdasarkan Hasil Survei Penduduk Antar Sensus menunjungkan, Angka Kematian Bayi sebesar 22,23 per 1000 kelahiran, Begitu pula dengan angka kematian balita, yang mendapat hasil survei sebesar 26,29 per 1000 kelahiran. $^{7}$

Program Inisiasi Menyusui Dini (IMD) ini merupakan kebijakan dari World Health Organization (WHO) dan United Nations Children's Fund (UNICEF) yang sekarang telah didukung oleh pemerintah Indonesia, sebagai tindakan "menyelamatkan nyawa", karena melalui program ini dapat menyelamatkan $22 \%$ bayi yang meninggal sebelum usia satu bulan. ${ }^{8}$

Berdasarkan hasil Riset

Kesehatan Dasar (Riskesdas) menunjukan pelaksanaan Inisiasi Menyusui Dini di Indonesia pada tahun 2013 sebesar 34,5\%. Di Provinsi Sumatera Utara sendiri pelaksanaan program Inisiasi Menyusui Dini (IMD) masih di bawah standar nasional yaitu $<34,5 \%$. ${ }^{9}$

Motivasi merupakan suatu dorongan, daya penggerak atau kekuatan yang menyebabkan suatu tindakan. ${ }^{10}$ Pengetahuan sangat penting dalam membentuk tindakan seseorang. Dengan adanya pemberian pengetahuan yang baik dapat mempengaruhi keinginan seorang ibu dalam melaksanakan Inisiasi Menyusui Dini. ${ }^{11}$

Oleh karena itu, penelitian ini dilakukan untuk mengetahui hubungan tingkat pengetahuan terhadap motivasi ibu hamil trimester III dalam melaksanakan inisiasi menyusui dini. Penelitian ini diharapkan dapat meningkatkan pengetahuan ibu hamil dan memotivasi ibu hamil untuk 
melaksanakan Inisiasi Menyusui Dini sehingga presentasi Inisiasi Menyusui Dini dapat ditingkatkan dan angka kematian bayi juga dapat diturunkan

\section{METODE PENELITIAN}

Jenis penelitian yang dilakukan bersifat deskriptif analitik dengan desain cross-sectional yang bertujuan untuk mengetahui hubungan tingkat pengetahuan terhadap motivasi ibu hamil trimester III dalam melaksanakan inisiasi menyusui dini.

Penelitian ini dilakukan di Puskesmas Medan Denai di Jl. Jermal XV, Medan Tenggara, Medan Denai, Kota Medan. Metode penarikan sampel pada penelitian ini yaitu purposive sampling. Sampel penelitian ini adalah ibu hamil trimester III yang berjumlah minimal 50 orang dengan kriteria inklusi peserta bersedia menjadi responden, dan hadir saat kunjungan ANC. Data yang digunakan dalam penelitian ini didapat dengan menggunakan kuisioner. Data yang terkumpul dalam penelitian ini dianalisis secara univariat dan bivariat. Analisis univariat dilakukan untuk melihat gambaran distribusi frekuensi pada variabel independen (tingkat pengetahuan) dan variabel dependen (motivasi) yang diteliti. Analisis bivariat dilakukan untuk mengetahui kemaknaan hubungan variabel independen dan variabel dependen. Uji statistik yang digunakan untuk membantu analisis adalah uji $C h i$ Square.

\section{HASIL PENELITIAN \\ Karakteristik Responden}

Dari penelitian terdapat 50 responden mengenai hubungan tingkat pengetahuan terhadap motivasi ibu hamil trimester III dalam melaksanakan inisiasi menyusui dini di Puskesmas Medan Denai dapat dilihat dari tabel 1.

Berdasarkan tabel 1 didapatkan hasil bahwa umur ibu hamil trimester III di Puskesmas Medan Denai sebagian besar berumur 20-35 tahun yaitu sebanyak 48 orang $(96 \%)$.

Berdasarkan tabel 1 didapatkan hasil bahwa jumlah kehamilan terbanyak adalah kehamilan pertama yaitu sebanyak 26 orang $(52 \%)$.

Berdasarkan tabel 1 didapatkan hasil bahwa sebagian besar responden usia kehamilannya adalah 28-31 minggu yaitu sebanyak 19 orang $(38 \%)$.

Berdasarkan tabel 1 didapatkan hasil bahwa responden terbanyak adalah dengan pendidikan SMA yaitu sebanyak 20 orang $(40 \%)$.

Berdasarkan table 1, didapatkan hasil bahwa responden terbanyak adalah dengan pekerjaan IRT (Ibu Rumah Tangga) yaitu sebanyak 39 orang (78\%).

Analisis Univariat

Distribusi Frekuensi Berdasarkan Tingkat Pengetahuan

Dalam penelitian ini tingkat pengetahuan dibedakan menjadi 3 
Vol 1 No 1 Desember 2019

kategori yaitu baik, cukup, dan responden pada penelitian ini adalah kurang Baik yang ditentukan oleh 50 orang.

hasil perhitungan kuisoner. Jumlah

Tabel 1. Karakteristik Responden

\begin{tabular}{|c|c|c|}
\hline $\begin{array}{c}\text { Umur } \\
\text { ( Tahun ) }\end{array}$ & Frekuensi & $\begin{array}{c}\text { Persentase } \\
(\%)\end{array}$ \\
\hline $20-35$ & 48 & 96,0 \\
\hline$>35$ & 2 & 04.0 \\
\hline Total & 50 & 100,0 \\
\hline Kehamilan Ke & Frekuensi & Persentase (\%) \\
\hline 1 & 26 & 52,0 \\
\hline 2 & 6 & 12,0 \\
\hline$\geq 3$ & 18 & 36,0 \\
\hline Total & 50 & 100,0 \\
\hline $\begin{array}{c}\text { Usia Kehamilan } \\
\text { (Minggu) }\end{array}$ & Frekuensi & Persentase $(\%)$ \\
\hline $28-31$ & 19 & 38,0 \\
\hline $32-35$ & 18 & 36,0 \\
\hline $36-40$ & 13 & 26,0 \\
\hline Total & 50 & 100,0 \\
\hline Pendidikan & Frekuensi & Persentase $(\%)$ \\
\hline SMP & 10 & 20,0 \\
\hline SMK & 12 & 24,0 \\
\hline SMA & 20 & 40,0 \\
\hline S1 & 8 & 16,0 \\
\hline Total & 50 & 100,0 \\
\hline Pekerjaan & Frekuensi & Presentase $(\%)$ \\
\hline IRT & 39 & 78,0 \\
\hline Wiraswasta & 7 & 14,0 \\
\hline Karyawan & 4 & 08,0 \\
\hline Total & 50 & 100,0 \\
\hline
\end{tabular}


Vol 1 No 1 Desember 2019

Tabel 2. Distribusi Frekuensi Berdasarkan Tingkat Pengetahuan Ibu Hamil Trimester III Tentang Inisiasi Menyusui Dini

\begin{tabular}{ccc}
\hline Pengetahuan & Frekuensi & $\begin{array}{c}\text { Persentase } \\
(\boldsymbol{\%})\end{array}$ \\
\hline & & \\
Baik & 9 & 18,0 \\
Cukup & 24 & 48,0 \\
Kurang Baik & 17 & 34,0 \\
\hline Total & 50 & 100,0 \\
\hline
\end{tabular}

Berdasarkan tabel 2, didapatkan hasil bahwa ibu hamil trimester III yang memiliki tingkat pengetahuan baik adalah sebanyak 9 orang (18\%), ibu hamil trimester III yang memiliki tingkat pengetahuan cukup adalah sebanyak 24 orang (48\%), dan ibu hamil trimester III yang memiliki tingkat pengetahuan kurang baik adalah sebanyak 17 orang (34\%).

\section{Distribusi Frekuensi Berdasarkan Motivasi}

Dalam penelitian ini Motivasi dibedakan menjadi 3 kategori yaitu Kuat, Sedang, dan Lemah yang ditentukan oleh hasil perhitungan kuisoner. Jumlah responden yang diteliti pada penelitian ini adalah 50 orang
Tabel 3. Distribusi Frekuensi Berdasarkan Motivasi Ibu Hamil Dalam Melaksanakan Inisiasi Menyusui Dini

\begin{tabular}{ccc}
\hline Motivasi & Frekuensi & $\begin{array}{c}\text { Persentase } \\
(\%)\end{array}$ \\
\hline Kuat & 29 & 58,0 \\
Sedang & 21 & 42,0 \\
Lemah & 0 & 00,0 \\
\hline Total & 50 & 100,0 \\
\hline
\end{tabular}

Berdasarkan tabel 3, didapatkan hasil bahwa ibu hamil trimester III yang memiliki motivasi kuat adalah sebanyak 29 orang (58\%),sedangkan ibu hamil trimester III yang memiliki motivasi sedang adalah sebanyak 21 orang (42\%). Sehingga dapat disimpulkan bahwa ibu hamil trimester III tidak ada yang memiliki Motivasi yang lemah dalam melaksanakan Inisiasi Menyusui Dini.

\section{Analisis Bivariat}

Dalam analisis bivariat peneliti menggunakan uji statistik dengan Chi Square dimana peneliti ingin mengetahui ada tidaknya hubungan tingkat pengetahuan terhadap motivasi ibu hamil trimester III dalam melaksanakan inisiasi menyusui dini di Puskesmas Medan Denai. Tingkat kemaknaan yang dipakai adalah $\alpha=0,05$. Variabel akan dikatakan berhubugan secara signifikan apabila nilai $\mathrm{p}<0,05$. 
Tabel 4. Hubungan Tingkat Pengetahuan Terhadap Motivasi Ibu Hamil Trimester III Dalam Melaksanakan Inisiasi Menyusui Dini Di Puskesmas Medan Denai.

\begin{tabular}{|c|c|c|c|c|c|c|c|c|c|}
\hline \multirow{3}{*}{$\begin{array}{c}\text { Tingkat } \\
\text { Pengetahuan }\end{array}$} & \multicolumn{6}{|c|}{ Motivasi } & \multirow{2}{*}{\multicolumn{2}{|c|}{ Total }} & \multirow{3}{*}{$\begin{array}{c}\mathrm{P} \\
\text { Value }\end{array}$} \\
\hline & \multicolumn{2}{|c|}{ Kuat } & \multicolumn{2}{|c|}{ Sedang } & \multicolumn{2}{|c|}{ Lemah } & & & \\
\hline & $\mathrm{N}$ & $\%$ & $\mathrm{~N}$ & $\%$ & $\mathrm{~N}$ & $\%$ & $\mathrm{n}$ & $\%$ & \\
\hline Baik & 8 & 88,9 & 1 & 11,1 & 0 & 0,0 & 9 & 100 & \\
\hline Cukup & 15 & 62,5 & 9 & 37,5 & 0 & 0.0 & 24 & 100 & 0,026 \\
\hline Kurang Baik & 6 & 35,3 & 11 & 64,7 & 0 & 0,0 & 17 & 100 & \\
\hline Total & 29 & & 21 & & 0 & & 50 & & \\
\hline
\end{tabular}

$\begin{array}{rccc}\text { Dari } & \text { tabel } & 4 & \text { diatas } \\ \text { menunjukan } & \text { bahwa } & \text { ibu } & \text { hamil }\end{array}$ trimester III yang tingkat pengetahuannya baik dan motivasi kuat sebanyak 6 orang $(85,71 \%)$, ibu hamil trimester III yang tingkat pengetahuannya baik dan motivasi sedang sebanyak 1 orang (14,29\%), dan ibu hamil trimester III yang tingkat pengetahuanya baik dan motivasi lemah tidak didapatkan $(0,0 \%)$. Ibu hamil trimester III yang tingkat pengetahuannya cukup dan motivasi kuat sebanyak 17 orang (68\%), ibu hamil trimester III yang tingkat pengetahuannya cukup dan motivasi sedang sebanyak 8 orang (32\%), dan ibu hamil trimester III yang tingkat pengetahuannya cukup dan motivasi lemah tidak didapatkan $(0,0 \%)$. Sedangkan ibu hamil trimester III yang tingkat pengetahuannya kurang baik dan motivasi kuat sebanyak 9 orang (50\%), ibu hamil trimester III yang tingkat pengetahuannya kurang baik dan motivasi sedang sebanyak 9 orang (50\%), dan ibu hamil trimester III yang tingkat pengetahuannya kurang baik dan motivasi lemah tidak didapatkan.

\section{PEMBAHASAN}

Berdasarkan tabel 1, karakteristik responden menurut umur ibu hamil trimester III sebagian besar berumur 20-35 tahun sebanyak 48 orang (96\%). Hal ini sesuai dengan penelitian sebelumnya yang dilakukan oleh Sigit Wiendarto pada tahun 2014 didapatkan responden sebagian besar berumur 20-35 tahun sebanyak 59 orang $(84,3 \%){ }^{11}$

Pada umur 20 - 35 tahun merupakan usia produktif sehingga daya tangkap mereka dalam menerima dan mengolah informasi yang diterima cukup baik. Hal ini memungkinkan ibu hamil trimester III memiliki daya tangkap terhadap informasi mengenai inisiasi menyusui dini yang cukup baik, serta menjadi dasar dalam menyikapi, mendukung, dan cenderung melaksanakan inisiasi menyusui 
dini. $^{12}$

Pada tabel 1 menunjukkan karakteristik responden berdasarkan jumlah kehamilan sebagian besar adalah kehamilan ketiga yaitu sebanyak 18 orang responden $(36 \%)$. Pengalaman sendiri merupakan faktor yang mempengaruhi pengetahuan serta mempengaruhi keberhasilan pelaksanaan inisiasi menyusui dini. ${ }^{13,14}$

Berdasarkan tabel 1 karakteristik responden menurut usia kehamilan sebagian besar ialah usia kehamilan antara 28-31 minggu yaitu sebanyak 19 responden (38\%). Usia ini merupakan usia awal di trimester III yang merupakan saat yang tepat untuk diberikan penyuluhan tentang Inisiasi Menyusu Dini. Dimana diharapkan tenaga kesehatan agar dapat memberikan penyuluhan ataupun promosi kesehatan tentang inisiasi menyusui dini baik pada ibu yang telah melahirkan maupun yang sedang dalam masa kehamilan. ${ }^{15}$ Pada tabel 1 menunjukkan karakteristik responden berdasarkan tingkat pendidikan sebagian besar ialah SMA yaitu sebanyak 20 orang (40\%). Hal ini sesuai dengan penelitian sebelumnya yang dilakukan oleh Mutia Aryani pada tahun 2011 didapatkan tingkat pendidikan responden sebagian besar ialah SMA sebanyak 16 orang (64\%). Pendidikan merupakan salah satu faktor yang mempengaruhi pengetahuan serta mempengaruhi keberhasilan pelaksanaan inisiasi menyusui dini. Dengan adanya tingkat pendidikan yang tinggi sangat mempengaruhi respon maupun sikap dalam menghadapi suatu hal yang datang dari luar. ${ }^{13,14}$

Berdasarkan tabel 1 karakteristik responden menurut pekerjaan ibu hamil trimester III sebagian besar adalah ibu rumah tangga sebanyak 39 orang (78\%). Hal ini sesuai dengan penelitian yang dilakukan oleh Suyani pada tahun 2013 dimana didapatkan responden sebagian besar sebagai ibu rumah tangga sebanyak 19 orang $(54,3 \%){ }^{15}$

Pada tabel 2 dan 3 diketahui bahwa ibu hamil trimester III di Puskesmas Medan Denai sebagian besar memiliki tingkat pengetahuan dalam kategori cukup sebanyak 24 orang (48\%), sedangkan motivasi ibu hamil trimester III di Puskesmas Medan Denai sebagian besar memiliki motivasi yang kuat sebanyak 29 orang (58\%).

Motivasi sebagai suatu keinginan yang terdapat pada diri seseorang yang mendorongnya untuk melakukan suatu perbuatan, tindakan, tingkah laku ataupun perilaku. ${ }^{16}$ Berdasarkan analisis dari hasil uji statistik chi-square didapatkan hasil $\mathrm{p}=0,026$ yang menunjukan angka yang signifikan, artinya ada hubungan yang bermakna antara tingkat pengetahuan terhadap motivasi ibu hamil trimester III dalam melaksanakan inisiasi menyusui dini di Puskesmas Medan Denai. Hal ini sejalan dengan 
penelitian yang dilakukan oleh Eka Yossy Septiana bahwa ada hubungan pengetahuan dan motivasi ibu hamil terhadap Inisiasi Menyusu Dini di Puskesmas Kenali Besar Kota Baru Jambi. ${ }^{17}$

\section{KESIMPULAN}

Berdasarkan hasil penelitian didapatkan umur ibu hamil trimester III di Puskesmas Medan Denai sebagian besar berumur 20-35 tahun (96\%), sebagian besar jumlah kehamilan adalah kehamilan pertama (52\%), usia kehamilan terbanyak adalah 28-31 minggu (38\%), pendidikan responden sebagian besar adalah SMA (40\%), dan sebagian besar responden adalah ibu rumah tangga (78\%).

Tingkat pengetahuan ibu hamil trimester III tentang inisiasi menyusui dini di Puskesmas Medan Denai cukup. Motivasi ibu hamil trimester III dalam melaksanakan inisiasi menyusui dini kuat. Ada hubungan yang bermakna antara tingkat pengetahuan terhadap motivasi ibu hamil trimester III dalam melaksanakan inisiasi menyusui dini di Puskesmas Medan Denai.

\section{DAFTAR PUSTAKA}

1. Satrinawati, Sutan R. The impact of maternal factors on neonatal mortality among low birth weight in Aceh Province, Indonesia. Int J Public Healt
Research. 2014; 4(2)

2. Sausan I. Perbedaan Tingkat Pengetahuan dan Sikap Ibu Hamil Sebelum dan Setelah Penyuluhan Mengenai IMD.Universitas Diponegoro. 2016

3. Miciński J, Pogorzelska J, Beisenov A, et al. Basic and mineral composition of colostrum from cows in different ages and calving period. $J$ of Elementology. 2017; 22(1):259-269

4. Takahashi K, Ganchimeg T, Ota E, et al. Prevalence of early initiation of breastfeeding and determinants of delayed initiation of breastfeeding: Secondary analysis of the WHO Global Survey. 2017; 7:1-10

5. World Health Organization. Status of the health-related SDGs. Geneva World Health Organization. 2017; 29-35

6. UN Inter-Group. Levels and trends in child mortality: Report 2015. UNICEF WHO World Bank Group United Nations. 2015; 74

7. Depkes RI. Profil Kesehatan Indonesia. Kementerian Kesehatan Republik Indonesia. 2013; 124-125

8. Ministry of Health Republic of Indonesia. Indonesian Health Profile 2013. 2013; 91-93.

9. Kemenkes RI. Pusat Data dan 
Vol 1 No 1 Desember 2019

Informasi Situasi dan Analisis

ASI Eksklusif. Kementrian

Kesehatan

Replubik

Indonesia. 2014; 5.

10. Septiana E, Hesty. Hubungan

Pengetahuan Dan Motivasi

Ibu Hamil Terhadap Inisiasi

Menyusu Dini Di Puskesmas

Kenali Besar Kota Jambi. 2015; 4(2):11-17

11. Wiendharti S. Hubungan Antara Pengetahuan Ibu, Motivasi Ibu, dan Dukungan Bidan Dengan Kesediaan Ibu Melakukan Inisiasi Menyusui Dini Di Wilayah Kerja Puskesmas Gajahan Kota

Surakarta. Fakultas Ilmu

Kesehatan Masyarakat

Universitas Muhammadiyah

Surakarta. 2016

12. Aryani M. Hubungan

Motivasi Ibu Dengan

Pelaksanaan Inisiasi

Menyusui Dini (IMD) Oleh

Ibu PostPartum Di BPS Umu

Hani Kasongan Bantul Yogyakarta.2011

13. Notoatmodjo S. Ilmu Perilaku

Kesehatan. Jakarta: Rineka Cipta. 2014

14. Risfiani H. Promosi Kesehatan, Dukungan Suami Dan Faktor Lain Hubungannya Dengan Inisiasi Menyusui Dini Di Wilayah Puskesmas DTP Wanaraja Garut. Fakultas Kesehatan Masyarakat Universitas Indonesia .2012
15. Suyani. Pengaruh Penyuluhan Inisiasi Menyusui Dini Terhadap Pengetahuan Dan Motivasi Melakukan Inisiasi Menyusui Dini Pada Ibu Hamil Trimester III Di BPS Yuni Baerozi Sorowajan Sewon Bantul Yogyakarta.2013

16. Wandini R. Hubungan Pengetahuan Dan Motivasi Ibu Terhadap Pelaksanaan Inisiasi Menyusui Dini (IMD) Di RSUD Menggala Tulang Bawang.2011

17. Septiana E, Hesty. Hubungan Pengetahuan Dan Motivasi Ibu Hamil Terhadap Inisiasi Menyusu Dini Di Puskesmas Kenali Besar Kota Jambi. 2015; 4(2):11-17 